Akreditasi KEMENRISTEKDIKTI, Nomor: 28/E/KPT/2019
http://jurnal.stkippersada.ac.id/iurnal/index.php/VoX

\title{
PENGEMBANGAN BAHAN AJAR E-BOOK MATEMATIKA DASAR BERBASIS METAKOGNISI MENGGUNAKAN FLIPBOOK MAKER UNTUK MAHASISWA PENDIDIKAN BIOLOGI STKIP PERSADA KHATULISTIWA SINTANG
}

\author{
Yasinta Lisa ${ }^{1}$, \& Nelly Wedyawati ${ }^{2}$ \\ ${ }^{1}$ Program Studi Pendidikan Komputer STKIP Persada Khatulistiwa Sintang \\ ${ }^{2}$ Program Studi Pendidikan Guru Sekolah Dasar STKIP Persada Khatulistiwa Sintang \\ Email : yasintalisa@gmail.com,nellywedyawati@ymail.com
}

\section{INFO ARTIKEL}

Riwayat Artikel:

Menerima : 31 Maret 2020

Revisi : 14 April 2020

Diterima : 28 April 2020

\section{Kata Kunci:}

Bahan Ajar E-Book,

Matematika Dasar, Metakognitif

\section{Keywords:}

E-Book Teaching Materials, Basic Mathematic,

Metacognitive

\section{Korespondensi:}

Yasinta Lisa

Program Studi Pendidikan Komputer STKIP Persada

Khatulistiwa Sintang

Email :yasintalisa@gmail.com

\section{ABSTRAK}

Pembelajaran Matematika selalu menjadi hal tersulit yang dirasakan mahasiswa sehingga tidak sedikit mahasiswa menganggap mata kuliah matematika dasar merupakan salah satu penghambat keberhasilan perkuliahan.Salah satu upaya yang dilakukan adalah tersedianya sumber belajar yang menarik yang mampu mengakomodasi mahasiswa untuk mampu menguasai pelajaran matematika dengan baik. Tujuan penelitian adalah mengembangkan bahan ajar berupa $e$-book untuk mata kuliah matematika dasar berbasis metakognitif.Penelitian ini merupakan penelitian pengembangan yang mengacu pada pengembangan Borg \& Gall yang dimodifikasi dengan tahapan berupa analisis kebutuhan, pengembangan produk dan evaluasi produk. E-book matematika dasar berbasis metakognitif dibuat menggunakan perangkat lunak flipbookmaker yang divalidasi oleh ahli materi dan ahli media dengan perolehan rata-rata nilai sebesar $88.5 \%$ dan $92.5 \%$. Penilaian tanggapan mahasiswa terhadap keterbacaan $e$-book sebesar $85.2 \%$ dengan kesimpulan bahwa bahan ajar $e$-book sangat layak untuk digunakan.

ABSTRACT
Mathematics learning has always been the hardest thing felt by students so that
not a few students consider basic mathematics courses to be one of the obstacles
to the success of lectures. One of the efforts made is the availability of interesting
learning resources that are able to accommodate students to be able to master
mathematics lessons well. The aim of the study was to develop teaching materials
in the form of e-books for metacognitive based elementary mathematics courses.
This research is a development research that refers to the development of Borg
$\&$ Gall which is modified by stages in the form of needs analysis, product
development and product evaluation. Metacognitive based elementary
mathematics e-books were made using flipbookmaker software which was
validated by material experts and media experts with the acquisition of an
average value of $88.5 \%$ and $92.5 \%$. Assessment of student responses to e-book
readability is $85.2 \%$ with the conclusion that e-book teaching materials are very
feasible to use.
C2020 LPPM STKIP Persada Khatulistiwa Sintang

\section{PENDAHULUAN}

Perkembangan teknologi informasi saat ini begitu pesatdapat hingga menyentuh berbagai bidang kehidupan tak terkecuali pendidikan dan pembelajaran. Salah satu trategi dan upaya yang dapat dilakukan dalam rangka meningkatkan 
mutu pendidikan adalah menerapkan teknologi dalam pembelajaran sehingga pembelajaran menjadi lebih baik (Supiandi \& Lisa, 2018)

Penerapan teknologi dalam aktivitas pembelajaran secara inovatif dapat menjadikan materi pembelajaran Sains menarik (Surjono, 2013). Penggunaan TIK sebagai sumber dan media pembelajaran dapat merangsang pikiran, perasaan, minat serta perhatian peserta didik sehingga proses pembelajaran dapat berjalan dengan baik (Dewi \& Hilman, 2018).

Media merupakan sarana komunikasi (Russell \& dkk, 2011). Media adalah bagian penting dari belajar dalam proses pembelajaran. Pembelajaran dengan e-book merupakan pembelajaran dengan menggunakan elektronik book yang dalam implementasinya memanfaatkan media elektronik (Wena, 2013).Adapun ciri e-book adalah dapat menyajikan deskripsi materi pelajaran yang mudah dimengerti, perangkat pembelajaran ebook memberikan kesempatan kesempatan kepada mahasiswa untuk melakukan praktik kegiatan pembelajaran (Siagian, 2014).

Salah satu cabang Sains yang dipelajari di sekolah adalah matematika. Matematika adalah ilmu yang membahas angka-angka dan perhitungannya, membahas masalah-masalah numerik, mengenai kuantitas dan besaran, mempelajari hubungan pola, bentuk dan struktur, sarana berfikir, kumpulan sistem, struktur dan alat (Hamzah \&Muhlisrarini, 2014). Menguasai matematika berarti memahami dan terampil menyelesaikan masalah dengan tahapan-tahapan tertentu. Paling sederhana dapat menguraikan langkahlangkah penyelesaikan masalah sekurangkurangnya tiga langkah penyelesaian soal. Secara substansial matematika berisi fakta, konsep, prinsip, skill dan keterampilan serta problem solving maka prosedural menyelesaikan soal itulah yang menjadi tujuan belajar matematika.

Pembelajaran matematika memiliki dua arah pengembangan yaitu untuk memenuhi kebutuhan masa kini dan kebutuhan masa mendatang. Visi pertama mengarahkan pengajaran matematika untuk pemahaman konsep-konsep yang kemudian diperlukan untuk menyelesaikan masalah matematika dan ilmu pengetahuan lainnya, visi kedua matematika memberikan kemampuan menalar yang logis, sistematik, kritis dan cermat serta bersikap obyektif dan terbuka dalam menghadapi masa depan yang selalu berubah (Jihat, 2008).

Pelajaran matematika pada sebagian peserta didik merupakan pelajaran yang menyulitkan. Kenyataannya di kelas menunjukkan bahwa tidak sedikit peserta didik yang berhasil dengan mudah dan gemilang mempelajarinya, namun masih banyak juga yang tidak berhasil mempelajarinya (Shadiq, 2014).

Hakikat pembelajaran matematika di perguruan tinggi berbeda dengan di tingkat sekolah. Dari tingkat dasar hingga menengah setiap orang mengatakan matematika itu 
penting yang ditunjukkan dengan terdapatnya pelajaran matematika hampir di setiap kurikulum program studi di tiap tingkatan tersebut di atas. Namun kenyataan menunjukkan bahwa matematika senantiasa menjadi permasalahan hampir di setiap program studi. Tidak banyak mahasiswa yang senang dengan mata kuliah matematika karena dianggap menghambat studi mereka. Setelah diamati, ada kecenderungan tidak terdapat kesungguhan dan dan kegembiraan belajar, tidak terjadi penyerapan materi ajar dengan baik dan benar. Akibatnya materi matematika tidak dikuasai sebagaimana mestinya bahkan sering terjadi misconception (Hamzah \& Muhlisrarini, 2014).

Tingkah laku kognitif merupakan tindakan mengenal atau memikirkan situasi dimana tingkah laku terjadi. Tingkah laku yang tergantung pada insight (pengamatan atau pemahaman) terhadap hubungan yang ada dalam situasi (Sumanto, 1998). Dalam kognisi terjadi proses berfikir dan proses mengamati yang menghasilkan, memperoleh, menyimpan dan memproduksi pengetahuan. Berfikir metakognitif memastikan bahwa mahasiswa mampu menyusun makna informasi. Agar hal ini dapat tercapai, mahasiswa harus mampu berfikir secara kreatif tentang proses berfikir yang dimilikinya, mengidentifikasi strategistrategi belajar yang baik dan secara sadar mengarahkan mereka cara mereka belajar.

Permasalahan yang kompleks yaitu ketika mahasiswa menyelesaikan soal-soal matematika. Mahasiswa terbiasa menyelesaikan soal-soal tersebut secara singkat dan langsung pada penyelesaiannya, tidak terfokus pada proses bagaimana memahami langkah demi langkah dalam penyelesaiannya. Selain itu, mahasiswa mengalami kesulitan dalam menyelesaikan soal-soal berbentuk soal cerita (soal aplikasi). Kesulitan tersebut didalam membaca makna yang tersirat dan kesulitan mengkonversi kedalam pernyataan matematika. Mahasiswa lebih mudah memahami atau menyelesaikan soal-soal berbentuk konsep atau pengertian dengan hanya menghafal saja. Hal ini disebabkan karena kemampuan berpikir mahasiswa belum sistematis dalam menyusun langkah-langkah penyelesaian. Dalam membantu mahasiswa menyelesaikan permasalahan di atas, diperlukan keterampilan dosen dalam mengelola kelas sehingga pembelajaran tidak menjenuhkan bahkan menyenangkan.

Pemberian masalah selama proses pembelajaran berlangsung, berarti memberikan kesempatan pada mahasiswa untuk membangun konsep dan mengembangkan keterampilannya sendiri. Tetapi agar dapat menyelesaikan suatu masalah setidaknya ada lima aspek kemampuan yang harus dikuasai mahasiswa yaitu: kemampuan tentang konsep matematika, kemampuan dalam menguasai keterampilan matematika, kemampuan proses memahami matematika, kemampuan untuk bersikap positif terhadap matematika dan kemampuan metakognitif. Pengetahuan 
metakognitif merujuk pada pengetahuan umum tentang bagaimana mahasiswa belajar dan memproses informasi, seperti pengetahuan mahasiswa tentang proses belajarnya sendiri. Pada prinsipnya jika dikaitkan dengan proses belajar, kemampuan metakognitif adalah kemampuan seseorang dalam mengontrol proses belajarnya, mulai dari tahap perencanaan, memilih strategi yang tepat sesuai masalah yang dihadapi, kemudian memonitor kemajuan dalam belajar dan secara bersamaan mengoreksi jika ada kesalahan yang terjadi selama memahami konsep, serta menganalisis keefektifan dari strategi yang dipilih.

Dalam Models of Teaching disebutkan bahwa dalam metakognitif ada proses "letting the student into the secret" sehingga peserta didik dapat membangun sendiri pengetahuan dan kemampuan mereka, memutuskan strategi belajar apa yang akan digunakan, pemecahan masalah, dan menemukan sendiri ilmu yang akan dipelajari. Oleh karena itu mahasiswa diharapkan mampu memotivasi diri sendiri, mengatur diri sendiri, mengembangkan diri, menentukan tujuan dan berusaha mencapai tujuannya (Joyce \& Marsha, 1996). Maka dapat dikatakan bahwa metakognitif memiliki peranan penting dalam mengatur dan mengontrol proses-proses kognitif seseorang dalam belajar dan berpikir, sehingga belajar dan berpikir yang dilakukan oleh seseorang menjadi lebih efektif dan efisien.

Salah satu aplikasi komputer yang dapat digunakan dalam belajar matematika menggunakan buku elektronik ini adalah software Flipbookmaker. Flipbookmaker merupakan perangkat lunak yang dinamis, bebas, dan multi-platform yang menggabungkan teks, gambar, video, animasi dan lain-lain yang dikemas secara bagus dan rapi sehingga mampu membuat mahasiswa dan dosen tertarik untuk meggunakannya.

Beberapa penelitian yang mengambil tema tentang penggunaan e-book dalam proses pembelajaran adalah (Dirgatama, Siswandari, \& Indrawati, 2017), (Jannah, Fadiawati, \& Tania, 2017), (Tuah, Herman, \& Maknun, 2018) dengan kesimpulan bahwa e-book memberikan respons positif siswa dalam pembelajaran di kelas serta mampu meningkatkan hasil belajar siswa. Penelitian pendekatan metakognitif dalam pembelajaran diantaranya (Iskandar, 2014), pengembangan bahan ajar dengan pendekatan metakognitif telah dilakukan diantaranya (Nugraha, 2011), (Nindiasari, 2011), dengan kesimpulan menunjukkan bahwa ketrampilan metakognitif yang diterapkan dalam pembelajaran memberikan dampak positif pada hasil belajar. Strategi metakognitif yang digunakan oleh guru berpengaruh terhadap ketrampilan berfikir tingkat tinggi siswa.

Dalam artikel ini akan dipaparkan tentang pengambangan e-book matematika dasar berbasis metakognisi menggunakan flipbook maker. Selain itu akan dipaparkan juga karakteristik dari $e$-book yang telah 
dikembangkan berdasarkan hasil uji coba lapangan awal.

\section{METODE PENELITIAN}

Metode penelitian yang digunakan dalam penelitian ini adalah metode penelitian dan pengembangan atau research and development (R\&D). Model pengembangan yang digunakan mengadaptasi dari model penelitian pengembangan yang dikembangkan oleh Borg \& Gall yang terdiri dari Analisis Kebutuhan, Pengembangan Produk dan Evaluasi Produk dengan tahapanyang ditampilkan pada Gambar 1.
Analisis

Kebutuhan

Pengembangan Produk

Evaluasi

Produk
Gambar 1. Model pengembangan bahan ajar e-book berbasis metakognitif menggunakan flipbookmaker pada mata kuliah Matematika Dasar (Adaptasi Borg \& Gall)

\section{Tahap Analisis Kebutuhan}

Studi pustaka dilakukan untuk mengumpulkan informasi tentang mata kuliah Matematika Dasar serta kemampuan metakognitif untuk menuangkannya dalam sebuah bahan ajar matematika.Studi lapangan dilakukan untuk melihat keadaan langsung di kelas. Data yang diperoleh bahwa pembelajaran mata kuliah matematika dasar mengandalkan buku teks dimana tidak semua mahasiswa memiliki.

\section{Tahap Pengembangan Produk}

Tahap ini merancang prototipe atau kerangka bahan ajar yang akan dibuat dan disesuaikan dengan analisis kebutuhan serta analisis karakter mahasiswa.Merumuskan penilai kelayakan dan sampel untuk melihat efektivitas. Menentukan prosedur kerja dan uji statistik kelayakan. Hasil dari kegiatan tersebut diperoleh draf desain produk yang siap untuk validasi.

\section{Tahap Evaluasi Produk}

Tahap evaluasi produk meliputi tahapan validasi produk dan uji coba produk. Tahap validasi bertujuan untuk menyempurnakan produk yang dibuat. Validasi dilakukan oleh pakar yang menguasai bidangnya. Pada tahap validasi dilakukan analisis dan revisi produk yang dibuat. Jika produk yang dibuat kurang baik, maka dilakukan revisi dan selanjutnya divalidasi kembali. Ahli pakar dalam penelitian adalah pakar pembelajaran Matematika dan pakar media pembelajaran.Uji coba produk dilaksanakan untuk memperoleh penilaian kelayakan buku dari pengguna yaitu dosen dan mahasiswa.Penilaian kelayakan buku dilakukan oleh 1 orang dosen pengampu mata kuliah dan 10 Mahasiswa yang sudah menempuh mata kuliah Pembelajaran Matematika Dasar.

Jenis data yang digunakan dalam penelitian ini adalah kualitatif dan kuantitatif. Data kualitatif diperoleh dari kritik dan saran dari para validator dan koresponden uji coba. 
Data kuantitatif diperoleh dari data hasil validasi dari para validator dan dari data uji coba. Instrument yang digunakan meliputi: lembar validasi oleh ahli materi dan ahli media; dan angket keterbacaan mahasiswa dan dosen.
Penilaian yang termuat dalam instrument lembar validasi Ahli materi mencakup aspek Kelayakan isi, Kelayakan Penyajian dan Kelayakan Bahasa. Secara lebih rinci tertuang dalam Tabel 1 berikut:

Tabel 1. Kisi-kisi Instrumen Lembar Validasi Ahli Materi Mata Kuliah Matematika Dasar

\begin{tabular}{clll}
\hline No. & Aspek yang Divalidasi & & \multicolumn{1}{c}{ Indikator } \\
\hline 1. & Kelayakan Isi & a. & Kesesuaian Materi dengan Capaian Pembelajaran \\
& & b. & Keakuratan Materi \\
& & c. & Kemutakhiran Materi \\
2. Kelayakan Penyajian & d. & aendorong Keingintahuan \\
& & a. & Teknik Penyajian \\
& belayakan Bahasa & c. Pendukung Penyajian \\
& & d. Konerensi dan Keruntutan Alur Pikir \\
& & a. Lugas \\
& & b. Komunikatif \\
& & c. Dialogis dan Interaktif \\
& & d. Kesesuaian dengan Perkembangan Peserta Didik
\end{tabular}

Penilaian yang termuat dalam instrumen lembar validasi Ahli Media mencakup aspek Kelayakan kegrafikan dengan indikator ukuran bahan ajar, dasain sampul bahan ajar (cover) serta desain isi bahan ajar. Secara lebih rinci kisi-kisi penilaian instrumen lembar validasi ahli media tertuang dalam tabel 2 berikut:

Tabel 2. Kisi-kisi Instrumen Lembar Validasi Ahli Media

\begin{tabular}{ccll}
\hline No. & Aspek yang Divalidasi & \multicolumn{1}{c}{ Indikator } \\
\hline 1. & Kelayakan Kegrafikan & a. & Ukuran Bahan Ajar \\
& & b. & Desain Sampul Bahan Ajar (Cover) \\
& & c. & Desain Isi Bahan Ajar \\
\hline
\end{tabular}

Penilaian yang termuat dalam instrumen angket respon mahasiswa mencakup beberapa indikator antara lain keterterikan, materi dan bahasa yang digunakan dalam e-book. Secara lebih rinci termuat dalam kisi-kisi instrumen angket respon mahasiswa yang tertuang dalam tabel 3 berikut:

Tabel 3. Kisi-kisi Instrumen Angket Respon Mahasiswa

\begin{tabular}{ccll}
\hline No. & Aspek yang Dinilai & & Indikator \\
\hline 1. & Respon Mahasiswa & a. & Ketertarikan \\
& & b. & Materi \\
& & c. & Bahasa \\
\hline
\end{tabular}

Data yang diperoleh selanjutnya dianalisis menggunakan statistik deskriptif, $\quad \mathrm{P}=\frac{\sum \text { (seluruh skor jwb angket) }}{n \times \text { tertinggi } x \text { jml responden }} \times 100 \%$ dengan rumus sebagai berikut:

Keterangan: 


$$
\begin{array}{ll}
\mathrm{P} & =\text { Prosentase penilaian } \\
\mathrm{n} & =\text { jumlah seluruh item angket } \\
\text { tertinggi } & =\begin{array}{l}
\text { skor paling tinggi untuk } \\
\text { pilihan jawaban angket }
\end{array}
\end{array}
$$

Kriteria penilaian untuk menentukan kelayakan produk merujuk pada Slavin (1992:78) dengan uraian seperti ditampilkan dalam Tabel 4.

Table 4. Kriteria Kelayakan Bahan ajar e-book (sumber: Slavin, 1992)

\begin{tabular}{ccc}
\hline No. & Skala & Kriteria Kelayakan \\
\hline $\mathbf{1}$ & $85-100$ & Sangat Layak \\
$\mathbf{2}$ & $70-84$ & Layak \\
$\mathbf{3}$ & $55-69$ & Cukup Layak \\
$\mathbf{4}$ & $40-54$ & Kurang Layak \\
$\mathbf{5}$ & $25-39$ & Tidak Layak \\
\hline
\end{tabular}

\section{HASIL PENELITIAN}

\section{Tahap Analisis Kebutuhan}

Pada tahap ini dilakukan analisis kebutuhan tentang pentingnya ketersediaan bahan ajar Matematika Dasar dalam bentuk e-book dengan memanfaatkan perkembangan teknologi informasi yang mempertimbangkan kemudahan akses bahan ajar oleh mahasiswa.Analisis kebutuhan ini dilakukan terhadap mahasiswa Pendidikan Biologi STKIP Persada Khatulistiwa Sintang yang menempuh matakuliah Matematika Dasar.Hasil Kuisioner menunjukkan bahwa ketersediaan bahan ajar Matematika Dasar masih rendah sehingga dianggap perlu untuk membuat bahan ajar dalam pembelajaran Matematika Dasar untuk Mahasiswa Pendidikan Biologi. Dari hasil kuisioner yang diisi oleh mahasiswa didapat bahwa $86.9 \%$ mengatakan bahwa adanya buku ajar sangat penting dan sebanyak 13,1\% menyatakan penting. Keseluruhan mahasiswa sepakat bahwa bahan ajar sebaiknya mampu mengantar mereka dalam proses berfikir mandiri dalam konsep mengasah kemampuan metakognitif dalam menguasai materi Matematika. Sebanyak $78.3 \%$ mahasiswa setuju bahan ajar dibuat dalam bentuk $e$-book.

\section{Tahap Pengembangan Produk}

Sebelum melakukan pengembangan maka dilakukan tahap perancangan bahanajar meliputi:

\section{Pemilihan Sampul Bahan Ajar}

Sampul e-book didesain dengan memperhatikan karakteristik mata kuliah Matematika diantaranya memasukkan symbol-simbol matematika serta gambar kepala manusia yang menggambarkan konsep berfikir matematika seperti yang ditampilkan pada Gambar 2.
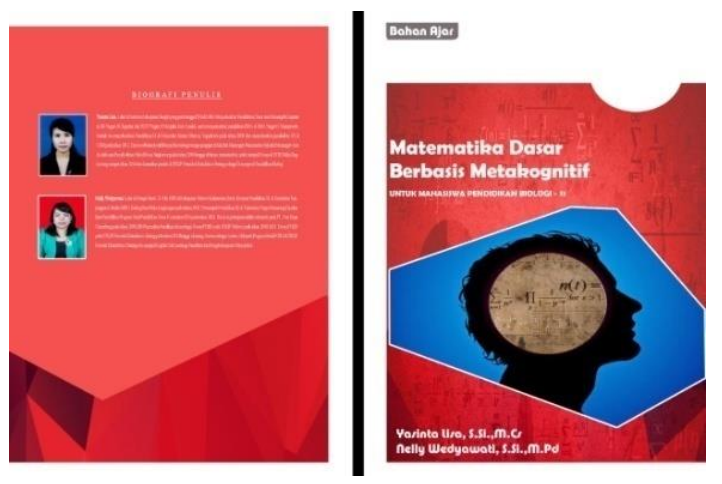

Gambar 2.Cover e-book Matematika Dasar Berbasis Metakognitif

\section{Komponen-komponen dalam Bahan ajar}

Komponen e-book sebagai Bahan Ajar meliputi: Kata Pengantar, Daftar Isi, Materi, Glosarium dan Daftar Pustaka. Setiap akhir Bab dalam materi diberikan angket evaluasi diri dalam mengerjakan setiap pertanyaan. Beberapa butir pernyataan angket akan berlaku untuk setiap pertanyaan penugasan. Pernyataan angket 
menuntun mahasiswa untuk memahami maksud dan tujuan soal serta proses penyelesaian soal sesuai dengan pemahaman mahasiswa masingmasing. Hal ini bertujuan untuk penekanan kemampuan metakognitif mahasiswa, sehingga mereka diharapkan mampu merencanakan pembelajaran dan mengevaluasi hasil belajar masing-masing.

\section{Pemilihan Materi Dalam Bahan Ajar}

Pemilihan materi mengacu pada kurikulum prodi Pendidikan Biologi STKIP Persada Khatulistiwa Sintang terutama komponen standar kompetensi dan deskripsi mata kuliah Matematika Dasar. Materi yang dimasukkan dalam Bahan Ajar ini meliputi : Bilangan Real, Himpunan dan macamnya, Fungsi, Logika Matematika, Irisan Kerucut, Integral Fungsi dan Persamaan Diferensial.

Tahapan selanjutnya merujuk pada tahapan pengembangan dengan melakukan uji validasi bahan ajar yang dinilai oleh 1 orang ahli materi dan 1 orang ahli media.Bahan ajar e-book mata kuliah Matematika Dasar untuk mahasiswa Pendidikan Biologi STKIP Persada Khatulistiwa Sintang yang telah tervalidasi oleh para validator dan teruji pada uji coba skala kecil.Berdasarkan data validasi oleh ahli materi dan ahli media masing-masing aspek dihitung prosentasenya. Prosentase yang diperoleh dicocokkan dengan tabel prosentase kelayakan produk pada Tabel 4.

Hasil rata-rata nilai e-book Matematika Dasar berbasis metakognitif dari validator ahli materi sebesar $88.5 \%$ sehingga dapat diambil kesimpulan bahwa secara keseluruhan dari aspek materi menyatakan bahwa e-book Matematika Dasar berbasis metakognitif tersebut mempunyai criteria Sangat Layak untuk digunakan. Ringkasan hasil validasi dari ahli materi ditampilkan dalam Tabel 5.

Table 5. Prosentase hasil Uji Validasi Ahli Materi

\begin{tabular}{lccccc}
\hline \multicolumn{1}{c}{ No. Aspek Validasi } & $\begin{array}{c}\text { Jumlah } \\
\text { Penilaian }\end{array}$ & Skor & $\begin{array}{c}\text { Skor } \\
\text { maksimal }\end{array}$ & \% & $\begin{array}{c}\text { Kriteria } \\
\text { Penilaian }\end{array}$ \\
\hline $\begin{array}{l}\text { A. Kelayakan Isi } \\
\text { 1. Kesesuaian Materi dengan }\end{array}$ & 3 & 10 & 12 & 83.3 & Layak \\
$\quad \begin{array}{l}\text { Capaian Pembelajaran } \\
\text { 2. Keakuratan Materi }\end{array}$ & 5 & 17 & 20 & 85 & Layak \\
3. Kemutakhiran Materi & 2 & 7 & 8 & 87.5 & Sangat Layak \\
$\begin{array}{l}\text { 4. Mendorong Keingintahuan } \\
\text { B. Kelayakan Penyajian }\end{array}$ & 2 & 8 & 8 & 100 & Sangat Layak \\
1. Teknik Penyajian & 1 & 4 & 4 & 100 & Sangat Layak \\
2. Pendukung Penyajian & 6 & 18 & 20 & 90 & Sangat Layak \\
3. Penyajian Pembelajaran & 1 & 4 & 4 & 100 & Sangat Layak \\
4. Koherensi dan Keruntutan Alur & 2 & 6 & 8 & 75 & Layak \\
$\quad \begin{array}{l}\text { Pikir } \\
\text { C. Kelayakan Kebahasaan }\end{array}$ & & & & & \\
1. Lugas & 3 & 11 & 12 & 91.7 & Sangat Layak \\
2. Komunikatif & 1 & 3 & 4 & 75 & Layak \\
3. Dialogis dan Interaktif & 1 & 4 & 4 & 91.7 & Sangat Layak \\
4. Kesesuaian dengan Peserta & 2 & 6 & 8 & 75 & Layak \\
$\quad$ Didik & & & & $\mathbf{8 8 . 5}$ & Sangat Layak \\
\hline
\end{tabular}


Saran perbaikan dari validator ahli materi adalah sebagai berikut : (1) Sedikit perbaikan tata tulis yang salan; (2) Konten harus lebih diperkaya dengan gambar-gambar.

Hasil rata-rata nilai $e$-book Matematika Dasar berbasis metakognitif dari validator ahli media sebesar $92.5 \%$ sehingga dapat diambil kesimpulan bahwa secara keseluruhan dari aspek media pembelajaran menyatakan bahwa e-book Matematika Dasar berbasis metakognitif tersebut mempunyai criteria Sangat Layak untuk digunakan. Ringkasan hasil validasi dari ahli media ditampilkan dalam Tabel 6.

Table 6. Prosentase hasil Uji Validasi Ahli Media

\begin{tabular}{cccccc}
\hline No. $\quad$ Aspek Validasi & $\begin{array}{c}\text { Jumlah } \\
\text { Penilaian }\end{array}$ & Skor & $\begin{array}{c}\text { Skor } \\
\text { maksimal }\end{array}$ & \% & Kriteria Penilaian \\
\hline A. Kelayakan Kegrafikan & & & & & \\
1. Ukuran Bahan Ajar & 2 & 8 & 8 & 100 & Sangat Layak \\
2. Desain Sampul Bahan Ajar & 7 & 24 & 28 & 85.7 & $\begin{array}{c}\text { Sangat Layak } \\
\text { 3. Desain Isi Bahan Ajar } \\
\text { Rerata }\end{array}$ \\
$\quad 18$ & 66 & 72 & 91.7 & $\begin{array}{c}\text { Sangat Layak } \\
\text { Sangat Layak }\end{array}$ \\
\hline
\end{tabular}

Saran perbaikan dari validator ahli media adalah sebagai berikut : (1) Perpaduan warna cover diperbaiki dengan mengkombinasikan jenis warna cerah dan warna gelap.

\section{Uji Keterbacaan}

Uji keterbacaan bahan ajar e-book Matematika Dasar berbasis Metakognitif untuk mahasiswa Pendidikan Biologi STKIP Persada Khatulistiwa
Sintang dilakukan oleh mahasiswa Pendidikan Biologi angkatan 14 yang menempuh mata kuliah tersebut. Jumlah mahasiswa yang melakukan uji keterbacaan tersebut sebanyak 10 orang mahasiswa.Secara keseluruhan hasil rata-rata prosentase uji keterbacaan bahan ajar oleh mahasiswa sebesar $85.2 \%$ dengan Kriteria Sangat Layak.Ringkasan data hasil uji keterbacaan disajikan dalam Tabel 7.berikut.

Table 7.Analisis Hasil Uji Keterbacaan oleh Mahasiswa

\begin{tabular}{|c|c|c|c|c|c|c|}
\hline No. & Aspek Validasi & $\begin{array}{c}\text { Jumlah } \\
\text { Penilaian }\end{array}$ & Skor & $\begin{array}{c}\text { Skor } \\
\text { maksimal }\end{array}$ & $\%$ & Kriteria Penilaian \\
\hline 1. & Ketertarikan & 5 & 176 & 200 & 88 & Sangat Layak \\
\hline 2. & Materi & 6 & 196 & 240 & 81.7 & Layak \\
\hline 3. & $\begin{array}{l}\text { Bahasa } \\
\text { Rerata }\end{array}$ & 3 & 103 & 120 & $\begin{array}{l}85.8 \\
\mathbf{8 5 . 2}\end{array}$ & $\begin{array}{c}\text { Sangat Layak } \\
\text { Sangat Layak }\end{array}$ \\
\hline
\end{tabular}




\section{HASIL DAN PEMBAHASAN}

Studi Lapangan. Hasil dari studi lapangan yaitu dosen dan mahasiswa mengatakan perlu adanya pengembangan $e$ book berbasis metakognitif untuk mata kuliah matematika dasar yang mudah diingat dan dimengerti serta membantu mahasiswa memahami proses belajar dan mengevaluasi hasil belajar. Pengembangan bahan ajar e-book Matetamatika Dasar berbasis Metakognitif sebagai sumber belajar untuk mahasiswa Pendidikan Biologi STKIP Persada Khatulistiwa ini dilaksanakan dengan mengikuti model pengembangan Borg \& Gall.Tahapan-tahapan dalam model ini meliputi

1) Analisis Kebutuhan; 2) Pengembangan Produk dan 3) Evaluasi Produk.

Tahap pengembangan produk merujuk pada hasil validasi ahli materi dan ahli media. Hasil penilaian menunjukkan bahwa ahli materi memberikan penilaian sebesar 88,5 dengan kategori sangat layak digunakan dan ahli media memberikan penilaian sebesar 92,5 dengan kategori sangat layak digunakan.

Pengembangan $e$-book matematika dasar berbasis metakognitif dinilai validator materi sangat tepat dalam memotivasi siswa dalam belajar. Hal ini didukung oleh penelitian (Cheng, Cheng, \& Chen, 2012) dengan mengemukakan bahwa pembelajaran berbantuan multimedia dapat memperbaiki gaya belajar siswa, serta meningkatkan motivasi dan hasil belajar. Penelitian lain yang dilakukan oleh (Nusir, Alsmadi, Al-Kabi, \& Shardqah, 2010) menemukan bahwa penggunaan multimedia terbukti meningkatkan kemampuan pemahaman siswa terhadap pembelajaran.

Penelitian pengembangan ini akan menghasilkan sebuah produk berupa bahan ajar dalam bentuk $e$-book mata kuliah Matematika Dasar berbasis metakognitif dengan menggunakan software flipbookmaker. Berdasarkan penilaian dan saran dari ahli materi, ahli media dan respon mahasiswa atas keterbacaan $e$-book, secara umum bahan ajar ini memiliki keunggulan dibandingkan bahan ajar konvensional. Beberapa kelebihan yang dimiliki berupa tampilan bahan ajar yang mudah diakses dan dibawa kemana-mana. Hasil penilaian menunjukkan bahwa bahan ajar berupa $e$-book ini termasuk dalam kualifikasi Sangat Layak digunakan.

Uji coba produk dilakukan terhadap 10 orang mahasiswa. Hasil penilaian mahasiswa atas keterbacaan e-book menghasilkan kesimpulan bahwa $e$-book memiliki tampilan yang baik dan menarik sehingga membantu untuk memahami dan menguasai konsep matematika. Memiliki tingkat kejelasan yang baik antara tujuan pembelajaran, paparan materi, contoh soal dan evaluasi yang mudah dipahami mahasiswa. Hal ini menyatakan bahwa bahan ajar ini sangat menarik dan dapat digunakan sebagai media pembelajaran untuk menguasai konsep pembelajaran matematika di kelas.

\section{SIMPULAN}

Berdasarkan hasil analisis penelitian, temuan, dan pembahasan yang diuraikan sebelumnya maka dapat diambil kesimpulan Bahan ajar, e-book Matematika Dasar berbasis 
metakognitif yang dihasilkan telah memenuhi standar baik segi materi, kegrafikan dan keterbacaan. Validasi ahli materi memberikan penilaian dengan prosentase rata-rata sebesar $88.5 \%$ dengan kategori Sangat Layak digunakan. Validasi ahli media memberikan penilaian dengan prosentase rata-rata sebesar 92.5\% dengan kategori Sangat Layak digunakan. Tanggapan mahasiswa terhadap penggunaan bahan ajar e-book memberikan hasil dengan prosentase sebesar $85.2 \%$ dengan kategori Sangat Layak dengan kata lain cocok dengan kebutuhan mahasiswa.

\section{DAFTAR RUJUKAN}

Cheng, Y.-H., Cheng, J.-T., \& Chen, D.-J. (2012). The Effect of Multimedia Computer Assisted Instruction and Learning Style on Learning Achievement. WSEAS TRANSACTIONS on INFORMATION SCIENCE and APPLICATIONS , 24-35.

Dewi, S. Z., \& Hilman, I. (2018). Penggunaan TIK sebagai Sumber dan Media Pembelajaran Inovatif di Sekolah Dasar. Indonesian Journal of Primary Education Vol. 2, No. 2 ISSN: 2597-4866 , 48-53.

Dick, W., Carey, L., \& Carey, J. O. (2009). The systematic design of instruction. Ney York: Longman.

Dirgatama, C. H., Siswandari, \& Indrawati, C. D. (2017). The Effectiveness of Achieved E-Book Based Curriculum 2013 as an Effort to Improving Learning Outcomes in Vocational School. Journal of Education and Learning. Vol 11 (3), 251-256.

Hamzah, A., \& Muhlisrarini. (2014). Perencanaan dan Strategi Pembelajaran Matematika. Jakarta: PT. RajaGrafindo Perkasa.
Iskandar, S. M. (2014). Pendekatan Ketrampilan Metakognitif dalam Pembelajaran Sains di Kelas. Jurnal Erudio Vol 2 No 2, 13-20.

Jannah, N., Fadiawati, N., \& Tania, L. (2017). Pengembangan E-Book Interaktif Berbasis Fenomena Kehidupan Seharihari tentang Pemisahan Campuran. Jurnal Pendidikan dan Pembelajaran Kimia, Vol 6, No. 1 , 186-198.

Jihat, A. (2008). Pengembangan Kurikulum MAtematika. Yogyakarta: Multi Pressindo.

Joyce, B., \& Marsha, W. (1996). Models of Teaching. Mars: Allyn \& Bacon.

Nindiasari, H. (2011). Pengembangan Bahan Ajar dan Instrumen untuk Meningkatkan Berfikir Reflektif Matematis Berbasis Pendekatan Metakognitif pada Siswa Sekolah Menengah Atas (SMA). Matematika dan Pendidikan Karakter dalam Pembelajaran ISBN : 978-97916353-6-3, (hal. 251-263). Yogyakarta.

Nugraha, A. (2011). Pengembangan Perangkat Pembelajaran Matematika dengan Pendekatan Metakognitif Berbasis Humanistik untuk Menumbuhkan Berfikir Kristis Siswa pada MAteri Himpunan Kelas VII. Jurnal PP Vol 1, No 1, 1-9.

Nusir, S., Alsmadi, I., Al-Kabi, M., \& Shardqah, F. (2010). Designing an Interactive Multimedia Learning System for the Children of Primary Schools in Jordan. IEEE Global Engineering Education Conference (EDUCON)"Learning Environments and Ecosystems in Engineering Education", (hal. 45-51). Amman.

Russell, J., \& dkk. (2011). Instructional Technology and Media For Learning. Jakarta: Kencana.

Shadiq, F. (2014). Pembelajaran Matematika: Cara Meningkatkan Kemampuan Berfikir Siswa. Yogyakarta: Graha Ilmu. 
Siagian, S. (2014). Development of Basic Electronic Instructional Module and Trainer. Journal of Computer Science and Information Technology Vol 2 No 3.

Sugiyono. (2014). Metode Penelitian Kuantitatif, Kualitatif, dan $R \& D$. Bandung: Alfabeta.

Sumanto, W. (1998). Psikologi Pendidikan, Landasan Kerja Pemimpin Pendidikan. Jakarta: Rineka Cipta.

Supiandi, M. I., \& Lisa, Y. (2018). The utilization of information and communication technology (ICT) on learning in the 21 st century. International Journal of Academic Research and Development, Volume 3; Issue 2 , 869875.

Surjono, H. D. (2013). Peranan Teknologi Informasi dan Komunikasi (ICT) dalam Peningkatan Proses Pembelajaran yang Inovatif. Seminar Nasional Pendidikan \& Saintec (hal. 1-10). Solo: UNS.

Tuah, Herman, N. D., \& Maknun, J. (2018). EBook in Teaching and Learning Process. 5th UPI International Conference on Technical and Vocational Education and Training (ICTVET 2018) (hal. 281-287). Bandung: Atlantis Press.

Wena, M. (2013). Pengembangan E-book Bermuatan Model Perubahan Konseptual dalam Pembelajaran Fisika di SMA. Jurnal Santi Aji Pendidikan Vol 1 No 1 . 